\title{
STRATEGI KOMUNIKASI PARIWISATA: MENCIPTAKAN SEMINYAK MENJADI TOP OF MIND TUJUAN WISATA DI BALI
}

\author{
Ilona Vicenovie Oisina Situmeang \\ Pascasarjana Ilmu Komunikasi \\ Universitas Persada Indonesia-YAI, Jakarta \\ Email: ilonaoisina@yahoo.com
}

\begin{abstract}
ABSTRAK
Sektor pariwisata setiap negara dapat meningkatkan perekonomian dan mendatangkan devisa bagi negara. Indonesia merupakan negara yang memiliki banyak tujuan wisata alam dan budaya, salah satunya adalah Bali. Bali menawarkan berbagai pesona keindahan wisata alam dan budaya yang dapat dinikmati wisatawan, salah satunya daerah Seminyak. Dalam penelitian ini meneliti strategi komunikasi pariwisata menciptakan Seminyak menjadi top of mind tujuan wisata di Bali. Dengan menggunakan pendekatan kualitatif, sifat penelitian deskriptif. Pengumpulan Data dilakukan dengan wawancara kepada beberapa wisatawan asing, lokal dan masyarakat setempat, observasi dan FGD. Hasil yang didapatkan bahwa dalam meningkatkan pariwisata suatu wilayah, strategi komunikasi pariwisata sangat dibutuhkan dengan merancang pesan oleh pemerintah daerah, dinas pariwisata, pelaku bisnis pariwisata dan masyarakat lokal. Memilih media promosi komunikasi dalam penyampaian pesan pariwisita yang menarik melalui media cetak, elektronik dan media online. Pariwisata di Seminyak terlihat dari meningkatnya sarana dan prasarana pariwisata yang menjadi salah satu daya tarik wisatawan untuk berkunjung ke Seminyak, seperti hotel, villa, money changer, shoping center, salon dan spa, resoran dan kuliner, cafe dan club malam tersedia diwilayah Seminyak.
\end{abstract}

Kata kunci: Strategi Komunikasi, Pariwisata, Top of Mind, Seminyak, Bali.

\begin{abstract}
The tourism sector in each country if well developed will increase the economy and foreign exchange for a country. Indonesia is one of the country that has many natural and cultural tourism destinations, one of them is Bali. Bali offers a variety of the beauty of nature and cultural charm that tourists can enjoy, one of the areas in Bali that continues to experience development is Seminyak.In this study the author examines the development of Seminyak tourism which is one of the mainstay tourist destinations in Bali.This is a descriptive study and using a qualitative approach. Data collection was carried out by interviewing several foreign tourists, local tourist and local people, observation and FGD. The results obtained that to increase tourism in an area, the region must already have tourism activities, so that it can continue to grow. The development of tourism in Seminyak can be seen from the increase in tourism facilities and infrastructure which is one of the attractions for tourists to visit Seminyak, such as hotels, villas, money changers, shoping centers, salons and spas, restaurants and culinary, cafes and night clubs that available in the Seminyak area. But in every development of tourism activities and facilities must be accompanied by the development of the ability of local communities to provide excellent service for tourists.
\end{abstract}

Keywords: Communications strategic, Tourism, Tp of Mind, Seminyak, Bali.

\section{PENDAHULUAN}

Indonesia merupakan salah satu tujuan travelling di dunia (Situmeang, 2018) Indonesia merupakan negara kepulauan terbesar di dunia memiliki keindahan alam sangat luar biasa. Sekitar 5776 pulau besar maupun kecil yang berderet di daerah khatulistiwa menyimpan keindahan alam (Soemantri, 2008). Indonesia terletak di kawasan iklim tropis berada di belahan timur bumi yang selalu disinari matahari dan terjadi dua kali pergantian musim dalam setahun: kemarau dan hujan. Negara yang memiliki iklim tropis dilimpahi kekayaan alam.
Sebagai negara kepulauan memiliki iklim tropis, potensi Indonesia untuk mengembangkan industri pariwisata sangat besar. Potensi wisata adalah sumber daya yang terdapat di daerah yang bisa dikembangkan menjadi atraksi wisata yang dimiliki dan dapat dikembangkan menjadi atraksi wisata yang dimanfaatkan untuk kepentingan ekonomi dengan memperhatikan aspek lainnya (Kanom, 2015). Iklim merupakan faktor penarik wisatawan yang ingin berelaksasi lebih nyaman dari tempat tinggalnya. Fenomena ini terjadi di destinasi pariwisata utama Indonesia (Suwarto, 2011). 
Sektor pariwisata di tiap wilayah Indonesia memiliki strategi dalam mengelola wisata, memiliki keunikan dan daya tarik yang berbeda-beda. Salah satu destinasi pariwisata andalan di Indonesia adalah wisata pantai yang banyak terdapat di Bali. Bali dapat dijadikan keberhasilan pariwisata di Indonesia (Somantri, 2008). Wisata di Bali dikelola dengan baik pelayanan dan fasilitas dengan melibatkan kearifan masyarakat lokal, sehingga menjadikan Bali tempat wisata favorit mewujudkan Bali sebagai tujuan wisata yang nyaman (Hidayat, 2017).

Agar sektor pariwisata dapat berkembang optimal dibutuhkan strategi komunikasi yang melibatkan peran serta pemerintah daerah, dinas pariwisata, pelaku bisnis pariwisata dan masyarakat setempat secara sama dalam membangun daerah wisata.

Strategi komunikasi dan pengelolaan sektor pariwisata secara optimal dapat memberikan kesempatan bagi daerah dan masyarakat setempat hidup berdaya dan mandiri. Diharapkan dengan berkembangnya usaha di sektor pariwisata dapat mengurangi ketergantungan masyarakat dengan sumber daya alam, meningkatkan pendapatan masyarakat setempat.

Bali merupakan destinasi wisata unggul di Indonesia dikarenakan Bali terdapat wisata pantai sebagai daya tarik bagi wisatawan. Bali penyumbang jumlah wisatawan mancanegara terbesar (Wijaya, 2015). Bali dikujungi wisatawan dengan berbagai alasan, sekaligus sebagai penyumbangan devisa negara dan pendapatan daerah (Soemantri, 2018).

Bali menjadi destinasi wisata untuk menghabiskan waktu liburan dan membangun momen indah yang tidak akan terlupakan. Wisata budaya: Pura dan kesenian warga. Wisata alam terdiri dari bukit, danau dan pantai. Berbagai media konvensional dan media online membantu memperkenalkan keindahan alam yang mempesona. Perbukitan hijau dipenuhi dengan pepohonan tropis lengkap dengan area persawahan dan lembah, tempat yang begitu romantis dan eksotis.

Pantai Lovina dikenal dengan kumpulan lumbalumba jika beruntung wisatawan dapat melihat lumba-lumba yang mendekat pantai, pantai Melasti digunakan untuk prewed, pantai Tegal Wingi pasir putih dan air biru jernih, pantai Canggu tempat surfing, pantai Tanah Lot terdapat Pura dan ular dipahami sebagai penjaganya, pantai Amed dengan pasir hitamnya, pantai Seminyak ombak digunakan untuk berselancar. Pasir putih yang landau dan pemandangan matahari terbenamnya menjadi daya tarik. Di sekitar Pantai Seminyak tersedia fasilitas hiburan: bungalow, hotel, mall, dan restoran.
Pantai seminyak dengan pasir putih dan lembut. Berbagai spa, cafe mewah dan nightlife dapat membantu menghilangkan rasa penat, memiliki private villa, shopping center, fine dining dan tempat sunset indah dengan pantulan diatas air laut dan juga dapat melihat matahari terbit di daerah Bali. Kawasan Seminyak merupakan kawasan lebih tenang.

Strategi komunikasi pariwisata yang dibuat yang menjadikan Seminyak menjadi top of mind wisatawan menciptakan ketertarikan peneliti untuk melakukan penelitian ini. Penelitian ini dilakukan bertujuan untuk memaparkan dan mendeskripsikan mengenai strategi komunikasi pariwisata di kawasan wisata Seminyak di Bali yang mengalami pengembangan wisata seperti fasilitas, sarana dan prasarana, kearifan masyarakat lokal dan seminyak menjadi top of mind salah satu tujuan wisata andalan di Bali.

\section{TINJAUAN PUSTAKA}

\subsection{Strategi Komunikasi}

Strategi komunikasi merupakan panduan perencanaan komunikasi dan manajemen untuk mencapai tujuan strategi komunikasi harus menunjukan operasional secara taktis harus dilakukan, bahwa pendekatan (approach) bisa berbeda sewaktu-waktu tergantung situasi dan kondisi. Strategi komunikasi merupakan kombinasi terbaik dari semua elemen komunikasi mulai dari komunikator, pesan, saluran penerima sampai pengaruh yang dirancang untuk mencapai tujuan komunikasi optimal (Changara, 2013).

Strategi komunikasi yang digunakan dinas pariwisata, pemerintah daerah dalam memperkenalkan wisata Seminyak menjadi Top of mind. Komponen komunikasi yang menjadi kajian dalam strategi komunikasi, yaitu:

1. Komunikator: pihak yang menjalankan strategi komunikasi. Untuk menjadi komunikator yang baik dan dapat dipercaya maka komunikator harus memiliki daya tarik dan kredibilitas.

2. Pesan Komunikasi, yang disampaikan oleh komunikator kepada khalayak sasaran dalam strategi komunikasi memiliki tujuan tertentu. Tujuan inilah yang menentukan teknik komunikasi yang akan dipilih dan digunakan dalam strategi komunikasi. Perumusan pesan dengan mempertimbangkan situasi dan kondisi khalayak.

3. Media Komunikasi: alat yang digunakan untuk menyampaikan pesan komunikasi. Dalam strategi komunikasi, perlu mempertimbangkan pemilihan media yang tepat dan menjangkau khalayak sasaran dengan tepat dan cepat. 
4. Khalayak Sasaran, melakukan identifikasi khalayak sasaran adalah hal penting yang harus dilakukan oleh komunikator dan disesuaikan dengan tujuan komunikasi.

\subsection{Media Komunikasi}

Memperkenalkan pariwisata di Seminyak dengan menggunakan tiga bauran promosi: Periklanan, Promosi dan Hubungan Masyarakat (Nevita 2017). Salah satu pendukung untuk keberlanjutan suatu daerah wisata keikutsertaan kearifan lokal, yaitu merupakan pengetahuan dan pengelolaan lokal Situmeng (2016). Pratiwi dan Pinasti 2017 masyarakat lokal memainkan peranan penting dalam pengembangan pariwisata. Kearifan lokal menjadi ciri khas masing-masing daerah (Sugiarto, Jihan, 2018).

Pengembangan wisata berbasis kearifan lokal bersinergi membangun Seminyak menjadi destinasi wisata unggulan dan Top of mind tujuan wisata, dengan memiliki strategi pengemasan pesan melalui destination branding sebagai kekuatan merubah persepsi tujuan wisata. Perubahan images dilakukan melalui media relations. (Situmorang, 2008).

Dalam menyebarluaskan informasi dibutuhkan berbagai media komunikasi. Menurut Rogers (2003) beberapa tipologi media/saluran komunikasi, di antaranya:

1. Saluran interpersonal, yaitu komunikasi tatap muka dengan keluarga, tetangga/teman, pedagang alat usaha tani, penyuluh. Saluran interpersonal antar individu sangat efektif, ada dialog, interaktif, ada umpan balik langsung.

2. Saluran media massa, yaitu dalam bentuk tercetak dan elektronik. Tercetak adalah: koran pedesaan, majalah, brosur, buku, poster. Elektronik adalah radio, televisi, internet. Saluran media massa mempunyai potensi menyebarkan informasi dengan cepat.

Saluran interpersonal dapat membantu pengoptimalisasian wisata. Pemerintah daerah dapat memperkenalkan wisata melalui iklan di berbagai media lokal dan nasional, media cetak lokal dan nasional. Media promosi pariwisata dilakukan untuk mendeskripsikan peran media digunakan dalam mempromosikan pariwisata (Nevita, 2017).

Pengguna media internet di Indonesia cukup tinggi menjadikan Indonesia menjadi pasar potensial untuk kegiatan pariwisata online. Promosi pariwisata melalui media online dapat dilakukan dengan mengunggah foto atau video yang menarik terjadi dalam waktu yang singkat, sifat media online yang real time, menekankan pada visual, fitur yang variatif, mudah digunakan dan efisien (Atiko dkk, 2016).

\section{METODE PENELITIAN}

\subsection{Desain Penelitian}

Pendekatan penelitian: kualitatif. Paradigma penelitian: paradigma post-positivisme. Tipe penelitian: eksploratif.

\subsection{Teknik Pengumpulan Data}

Teknik yang digunakan untuk mengumpulkan data diperoleh dari Data Primer, yang menjadi data primer adalah:

1. Wawancara Mendalam

2. Observasi

3. Focus Group Discussion

Data Sekunder, Data sekunder diperoleh melalui studi dokumentasi dan studi literatur. Diperoleh dari fotofoto kegiatan, surat kabar, website maupun kliping artikel yang memuat berita mengenai daya tarik wisata pantai Seminyak di Bali.

\subsection{Teknik Analisis Data}

Menurut Bodgan dan Biklen, Analisis data kualitatif merupakan upaya yang dilakukan dengan jalan bekerja dengan data, mengorganisasikan data, memilah menjadi satuan yang dapat dikelola, mensintesiskannya, mencari dan menemukan pola, menemukan apa yang penting dan apa yang dipelajari, serta memutuskan apa yang dapat diceritakan kepada orang lain. (Moleong 2010).

\section{HASIL DAN PEMBAHASAN}

Pembangunan di sektor kepariwisataan bertujuan untuk menggalakkan perekonomian nasional dan dan masyarakat lokal, sektor pariwisata menjadi penopang sektor penerimaan negara terbesar selain sektor migas. Pasar pariwisata internasional justru banyak menyumbangkan kecepatan, percepatan dan perkembangan pariwisata di negara berkembang. Pariwisata memiliki potensi yang memungkinkan terciptanya strategi pembangunan di negara berkembang sehingga dianggap sebagai pintu masuk kesejahteraan masyarakat. 
Kekuatan sektor pariwisata merupakan instrumen pembangunan dan pemberdayaan masyarakat lokal. Sektor pariwisata sebagai sumber penerimaan devisa negara, pariwisata memiliki banyak elemen yang dapat mendorong transformasi ekonomi, dari karakter negara pertanian yang tradisional menuju masyarakat modern industrial, dari kondisi masyarakat yang sub sistem menuju masyarakat yang berorientasi pasar (Hendarto, 2008).

Indonesia merupakan salah satu negara yang berlimpah dengan kekayaan alam yang dapat dikelola untuk dijadikan tempat wisata dan iklim tropis merupakan salah satu faktor penarik wisatawan yang ingin berelaksasi lebih nyaman daripada tempat tinggalnya. Mereka yang tinggal daerah dingin, berwisata ke iklim tropis seperti iklim yang terdapat di Indonesia (Suwarto Titania, 2011). Salah satu tempat yang nyaman dikunjungi adalah Bali.

Selama ini Bali dikenal sebagai tujuan wisata andalan bagi wisatawan asing dan lokal, sebagian besar wilayah di Bali dijadikan tujuan wisata dengan memiliki karakteristik wisata yang menarik hal ini tidak terlepas dari strategi komunikasi yang dilakukan oleh pemerintah daerah. Wisatawan yang datang ke Bali memilih wilayah dan lokasi yang dianggap paling nyaman untuk menghabiskan waktu berlibur.

Wisatawan asing mengetahui bahwa Bali itu Indonesia dan Indonesia itu Bali. Masyarakat Bali mayoritas beragama Hindu yang masih memegang kuat norma agama dan norma budaya dalam menjalani kehidupan sehari-hari. Masyarakat Bali memiliki sikap terbuka terhadap perubahan dan perkembangan pariwisata di daerahnya. Keikutsertaan masyarakat lokal dalam mengelola dan menjaga keasrian Bali menjadikan Bali tetap prioritas utama bagi tujuan wisatawan.

\subsection{Strategi Komunikasi Pariwisata Seminyak Bali Menjadi Top of Mind Wisatawan}

Wisata Alam dan budaya menjadi alasan utama wisatawan berkunjung ke Bali. Daya tarik utama Bali terdapat pada wisata alam salah satunya pantai. Terutama objek wisata pantai yang memiliki pasir putih dan hitam dengan pemandangan sunset. Di setiap tempat wisata di Bali memiliki keunikan dan keindahan tersendiri yang memberikan kesan berbeda. Lokasi pantai tersebar hampir di semua Bali dengan berbagai keunikan yang dimilikinya.
Pantai di Bali yang menjadi ikon adalah pantai Nusa Dua, Pantai Jimbaran, Pantai Kuta, Pantai Sanur, Pantai Tanah Lot dan akhir-akhir ini mulai banyak dikunjungi oleh wisatawan asing adalah Pantai Seminyak yang memiliki pasir putih yang halus. Seminyak Bali, merupakan salah satu tujuan wisata bagi wisatawan yang berkunjung ke Bali. Seminyak merupakan kelurahan administratif Kecamatan Kuta, Kabupaten Bali. Kawasan Seminyak berjarak sekitar 11 kilometer dari Bandara Udara Internasional Ngurah Rai dan bisa ditempuh dengan berkendara sekitar 26 menit.

Wilayah seminyak tidak jauh dengan kawasan pariwisata Nusa Dua berjarak sekitar 18 kilometer atau bisa di akses dengan berkendara sekitar 35 menit dengan menggunakan kendaraan. Wisata Seminyak merupakan tempat wisata yang nyaman dilengkapi dengan berbagai fasilitas wisata istimewa, tidak kalah dengan fasilitas di Nusa Dua Bali. Nusa Dua Bali dikenal sebagai tempat wisata yang Luxury Class terdapat banyak hotel bintang 5 yang bertaraf internasional.

Tempat luxury daerah Bali adalah Kawasan Nusa Dua biasanya wisatawan yang berkunjung berasal dari para pejabat dan tamu penting kenegaraan yang datang dan menginap di wilayah Nusa Dua Bali, sebagian berasal dari wisatawan yaitu Asia dan Eropa. Selain pejabat dan tamu penting kawasan Nusa Dua merupakan tempat wisatawan datang berkunjung bersama keluarga (family tourist).

Family tourist yang datang mengutamakan kenyamanan dan kualitas pelayanan, sehingga pengelompokkan wisatawan di Nusa Dua lebih tamu negara dan pejabat penting negara serta family turis yang berasal dari Asia dan Eropa.

Kawasan Nusa Dua memiliki daerah komplek pariwisata private memiliki pulau tersendiri sehingga biaya penginapan, kuliner dan berbelanja lebih mahal dibandingkan dengan wilayah lainnya. Nusa Dua merupakan wilayah private. Memiliki beberapa perbedaan dengan kawasan Seminyak yang menyediakan berbagai macam fasilitas yang lengkap untuk mendukung kenyamanan wisatawan mulai dari resort, hotel, private villas, restaurant, spa, cafe dan bar, shopping center hingga kawasan hiburan malam seperti night club.

Pengunjung yang datang ke Seminyak merupakan wisatawan asing yang berusia muda dan mereka datang tidak bersama keluarga melainkan dengan 
teman-teman. Melakukan kunjungan wisata dengan teman-teman menghabiskan malam di klub malam Seminyak menjadi daya tarik tersendiri bagi wisatawan.

Wisata Seminyak sangat ideal bagi wisatawan yang hobi berbelanja, fine dining, perawatan tubuh dengan Spa dan menghabiskan malam dengan teman-teman di Club malam semua tersedia. Seminyak merupakan wilayah yang hampir sama dengan Kuta (New Kuta), namun yang membedakan adalah Seminyak merupakan tempat wisata yang lebih modern, ramai dan urban. Untuk mendapatkan akses bepergian dan tempat makan, mall boutique lebih mudah dibandingkan dengan daerah Nusa Dua karena terdapat banyak pilihan.

Wisata Seminyak banyak digunakan untuk wisatawan yang ingin melakukan berbagai aktivitas kepariwisataan, seperti untuk menikmati matahari terbit dan matahari terbenam yang sangat indah. Pantai Seminyak memiliki kontur pesisir pantai yang landai, memiliki pasir putih lembut, mengingatkan dengan ciri pantai yang ada di Nusa Dua yang sangat terkenal seperti pantai Mengiat, dan Pantai Sawangan.

Pantai seminyak bersebelahan dengan pantai Kuta yang sering disebut dengan saudara kembaran karena letaknya yang berdampingan. Namun memiliki karakteristik pengunjung yang berbeda. Panti Seminyak merupakan wilayah yang dipilih oleh wisatawan yang memiliki hobi berselancar, berjemur dibawah teriknya matahari hingga wisatawan yang ingin menunggangi kuda di pesisir pantainya dan bermain dengan anjing di pinggir pantai. Saat-saat tertentu biasanya wisatawan dapat melihat penyu.

Sarana-prasarana yang ada di wilayah Pantai Seminyak yang dapat menunjang kemudahan dan Kenyamanan wisatawan yang berkunjung. Wisatawan nyaman untuk tinggal berlama-lama di daerah Seminyak. Pantai seminyak bisa dinikmati dalam dua waktu yang berbeda, yaitu di pagi dan malam hari. Pagi hari dan siang hari saat matahari terbit terlihat seolah pantai tidak berujung, namun berbeda dengan malam hari lebih tenang dan romantis, berjalan dipinggir pantai dengan diterangi cahaya lebih sedikit membuat suasana menjadi lebih damai.

Pantai di Seminyak ada Pantai Double Six, pantai ini dikenal karena letaknya berseberangan dengan sebuah diskotik Double Six. Daya tarik utama wisatawan yang berkunjung ke pantai double six dikarenakan lokasi merupakan tempat untuk wisatawan melihat sunset. Biasanya tempat ini ramai dikunjungi di sore hari. Wisatawan yang datang untuk melihat sunset kebanyakan kawula muda yang menikmati sunset dengan bersantai duduk di sofa berwarna-warni yang disediakan oleh cafe yang letaknya berderet sepanjang pantai.

Menikmati suasana eksotis dan romantis Sunset di Pantai Double Six akan semakin sempurna karena disekitar pantai tersebut banyak sekali tersedia sajian makanan dan minuman. Untuk harga makanan dan minuman yang ditawarkan cukup bervariasi sehingga dapat mencari makanan dan minuman yang sesuai dengan keinginannya.

Di daerah Seminyak terdapat banyak tempat berbelanja (shopping center) dan money changer. Untuk tempat berbelanja menyediakan berbagai produk merk lokal dan internasional. Wisatawan asing lebih memilih produk lokal yang memiliki ciri dan karakteristik yang unik yang merupakan kerajinan tangan masyarakat Bali. Berbagai kerajinan tangan dan oleh-oleh khas Bali dapat didapatkan di Seminyak Square.

Wisatawan lokal hobi berbelanja produk branded dengan harga yang super murah tersedia di Everything 100.000,- untuk semua tas, dompet, kaos, sepatu dll. Namun untuk store ini kurang diminati oleh wisatawan asing karena produk yang ditawarkan brand internasional.

Untuk kuliner di Seminyak bervariasi. Wisatawan dapat memilih menu apa yang dicari. Kuliner khas Indonesia dengan berbagai variasi harga. Untuk wisatawan asing yang belum terbiasa dengan kuliner Indonesia dapat memilih Resto yang menyajikan makanan dari berbagai negara.

Wisata Seminyak mengalami perkembangan daerah wisata yang cukup maju, terlihat dari semakin lengkap dan bertambahnya atraksi wisata alam dan budaya yang terdapat di daerah Seminyak Bali, sehingga menciptakan wilayah Seminyak menjadi salah satu tempat wisata yang topof mind bagi wisatawan. Hal ini tidak luput peran serta pemerintah daerah dan masyarakat setempat.

Motif wisatawan yang berkunjung beraneka ragam. Ada wisatawan lokal dan asing yang mengisi waktu liburan dan waktu luang. Biasanya untuk wisatawan lokal berkunjung hanya beberapa hari berbeda dengan 
wisatawan asing yang berkunjung biasanya menghabiskan waktu yang lebih lama dan lebih panjang dikarenakan merasa nyaman menikmati keindahan di Seminyak.

Wisatawan yang datang berkunjung sebagian besar mengetahui informasi Seminyak dari saluran media konvensional dan media online. Selain itu komunikasi word of mouth merupakan salah satu saluran komunikasi yang efektif untuk mempromosikan Seminyak.

Media digital sangat membantu memberikan informasi yang dapat diakses oleh setiap pengguna di seluruh dunia. Informasi yang disampaikan berikut dengan visualisasi yang menarik sehingga calon wisatawan dapat mendapatkan gambaran terhadap tujuan wisata yang diinformasikan, travel (tiket pesawat, hotel dan menikmati pesona seminyak) akan membantu wisatawan yang datang berkunjung ke Seminyak, Bali.

Tempat yang menarik, nyaman dan pelayanan prima menjadi daya tarik wisatawan yang berkunjung untuk berlama-lama menghabiskan waktu. Fasilitas dan penginapan yang menawarkan harga bervariasi menjadikan salah satu indikator wisatawan untuk tinggal berlama-lama di Seminyak Bali.

Kearifan masyarakat lokal dan pengetahuan masyarakat lokal dalam memberikan pelayanan yang baik dan memuaskan menjadikan Seminyak menjadi top of mind bagi wisatawan di Bali. Pengoptimalisasi kearifan lokal masyarakat setempat sudah maksimal, sikap terbuka dari masyarakat lokal menjadikan wisatawan nyaman saat berkunjung ke Seminyak, Bali.

\subsection{Komponen Strategi Komunikasi Pariwisata Seminyak, Bali}

\subsubsection{Komunikator Wisata}

Komunikator dalam strategi komunikasi ini adalah pemerintah daerah, dinas pariwisata, pelaku bisnis pariwisata dan masyarakat lokal. Perencanaan yang maksimal yang terus dirancang pemerintah daerah tidak hanya mengembangkan tempat tujuan wisata alam dan budaya saja namun juga harus mengembangkan kemampuan masyarakat lokal dalam melayani wisatawan.

Tindakan pariwisata menyatakan apa yang dilakukan, kapan akan dilakukan dan oleh siapa. Tourism Action
Steps harus jelas dan mempunyai jangka waktu yang ditentukan dan tujuan yang diharapkan. Pelaksanaan tindakan itu dapat didelegasikan secara individu atau berkelompok (Hidayat, 2011).

Pengetahuan dan pelayanan prima dari masyarakat lokal baik secara individu maupun kelompok menjadi salah satu faktor utama untuk kenyamanan wisatawan. Masyarakat lokal dibekali pengetahuan sebagai pelayan wisata seperti harus bersikap jujur terhadap wisatawan dan tidak melakukan perbuatan yang melanggar etika.

Pengetahuan budaya dan agama yang dijunjung tinggi menjadi indikator masyarakat lokal dalam memberikan pelayanan prima kepada wisatawan. Memberdayakan masyarakat lokal sebagai salah satu peluang menggerakkan segenap potensi dan dinamika masyarakat, guna mengimbangi peran pelaku usaha pariwisata. Menggali kearifan lokal yang dimiliki oleh para pelaku usaha pariwisata dalam hal ini adalah masyarakat lokal.

Menurut Sharpley (dalam Budiani dkk, 2018) kebijakan pembangunan pariwisata yang terarah pada penggunaan sumber daya alam dan penggunaan sumberdaya manusia untuk jangka waktu panjang. Pariwisata berbasis masyarakat lokal perlu diletakkan dalam konteks kerjasama masyarakat secara global dan terpadu hal ini tidak lepas dari peran pentingnya pemerintah daerah yang menjadi penggerak pariwisata berbasis masyarakat lokal.

Output jangka panjang tempat wisata yang diperoleh dimana masyarakat lokal memiliki kehidupan ekonomi yang terus meningkat, tingkat sosial budaya masyarakat mulai terarah. Potensi yang dimiliki masyarakat lokal untuk tercapainya top of mind Seminyak sebagai salah satu tempat wisata.

\subsubsection{Pesan Wisata}

Pesan pariwisata yang dikemas oleh pemerintah daerah bekerja sama dengan pelaku bisnis pariwisata melalui paket tour seminyak yang bervariasi seperti paket family tour, holiday tour dan complete tour. Wisatawan tinggal memilih paket apa yang sesuai dengan yang dicari. Melalui paket tour ini calon wisatawan akan mendapatkan informasi yang lengkap tentang wisata di Bali.

Pesan lain yang dikemas dalam bentuk promosi dan kerjasama dengan pelaku bisnis travel agent dan maskapai promo penerbangan dalam dan luar negeri. Menggelar berbagai event berskala internasional yang menarik perhatian wisatawan. 
Dalam paket yang disajikan pemerintah daerah selalu menghimbau kepada pelaku bisnis pariwisata untuk mengutamakan kejujuran dalam menyampaikan pesan sehingga wisatawan merasa nyaman dan berkeinginan untuk berlibur kembali ke Bali. Menjelang pergantian tahun, Imlek, lebaran, liburan sekolah dan Natal tour travel menyediakan berbagai promosi perjalanan wisata dari harga yang terjangkau hingga luxury.

Diharapkan dengan pesan wisata yang menarik sehingga kunjungan wisatawan semakin meningkat ke Seminyak Bali, memberikan kontribusi berupa pertumbuhan ekonomi masyarakatnya mulai berkembang dengan baik, melalui terbentuknya usahausaha masyarakat yang bersifat individual ataupun keluarga.

Masyarakat lokal memanfaatkan rumah tinggal untuk memenuhi kebutuhan wisatawan, dengan mengembangkan homestay dan toko-toko. Seiring dengan semakin pesatnya perkembangan kepariwisataan, menarik minat investor untuk menanam modal di Kawasan Seminyak yang ditandai dengan munculnya hotel berbintang dengan beragam fasilitas dan aktifitas, cafe dan club malam, shoping center.

Bagi masyarakat lokal sendiri kondisi ini justru memberikan kontribusi negatif terhadap perkembangan usaha homestay yang digeluti. Untuk menjaga kelangsungan hidupnya, masyarakat mulai beralih yang awalnya menawarkan homestay saat ini menawarkan kos-kosan.

Perkembangan kepariwisataan di Seminyak semakin berkembang dengan munculnya aktivitas wisata. Aktivitas kepariwisataan digemari oleh wisatawan, wisatawan datang ke pantai di Seminyak untuk menikmati keindahan pantai dengan pasir putih yang halus, berjemur di bibir pantai, bermain selancar.

Pesan wisata lain yang disampaikan oleh pelaku bisnis pariwisata untuk menarik jumlah kunjungan wisata melalui membuka peluang bagi masyarakat lokal untuk menambah pemasukan dengan membuka tempat penyewaan papan selancar, menjadi tutor selancar bagi wisatawan, membuka sekolah selancar bagi pemula.

Hal ini seperti pendapat Antari (2013), mengatakan bahwa perkembangan pariwisata akan berpengaruh pada kondisi masyarakat lokal seperti: penerimaan devisa, pendapatan masyarakat, kesempatan kerja, harga-harga, distribusi masyarakat dan keuntungan, kepemilikan dan kontrol, dampak terhadap pembangunan dan pendapatan pemerintah.

Perkembangan pariwisata berkelanjutan harus diikuti dengan pengembangan dan pelatihan bagi masyarakat lokal yang menjadi pelayan dalam berbagai kegiatan kepariwisataan di Seminyak. Memberdayakan masyarakat Bali dalam mendukung pengembangan kepariwisataan di Seminyak, Bali. Hal ini sesuai dengan hasil penelitian Budiani dkk, 2018 mengatakan bahwa: Strategi yang paling gencar digunakan dalam Pengembangann pariwisata berkelanjutan salah satunya, yaitu Pengembangan yang didasarkan atas prinsip pemberdayaan berbasis masyarakat.

\subsubsection{Media Promosi Wisata}

Media promosi yang digunakan oleh pelaku bisnis wisata adalah media konvensional dan media online. Media online paling efektif dalam menyampaikan pesan wisata menyebar keseluruh dunia sehingga dapat mudah untuk diakses.

Media promosi wisata Seminyak sebagai salah satu perantara penyampaian pesan wisata yang dirancang untuk diketahui oleh khalayak. Pesan tentang tujuan wisata di Bali harus selalu dirancang dengan baik dan menarik, sehingga memberikan daya tarik tersendiri bagi para pengguna media promosi.

Promosi melalui media sosial dengan Penciptaan konten wisata berfokus pada visual yang menarik yakni menampilkan foto ataupun video sehingga khalayak mendapatkan foto maupun video melalui tentang wisata Bali dan Seminyak. Memperbanyak tampilan foto dan video wisata alam dan budaya tanpa direkayasa.

Selain itu juga menentukan penentuan platform media sosial yang digunakan sebagai alat promosi wisata, pihak pemerintah daerah, dinas pariwisata dan juga pelaku bisnis wisata bekerja sama dalam memilih media sosial yang saat ini sedang disenangi oleh target market dan untuk pesan wisata tertentu akan memilih beberapa media sosial seperti melalui website, instagram, Facebook, Twitter dinilai media sosial memiliki potensi cukup tinggi untuk dijadikan media dalam kegiatan mempromosikan pariwisata Bali dan Seminyak.

Selain melakukan promosi melalui media online juga melakukan promosi dengan menggunakan media 
konvensional, yaitu media cetak dan media elektronik. Hal ini dikarenakan media massa masih mempunyai pengaruh cukup kuat bagi segmentasi dan targeting wisatawan tertentu. Membuat booklet dan leaflet yang menarik berisi tentang informasi Bali dan Seminyak.

\subsubsection{Komunikan Wisata}

Komunikan dalam penelitian ini adalah wisatawan yang berkunjung ke daerah seminyak. Dimana dari hasil observasi yang penulis lakukan bahwa kebanyakan wisatawan asing yang datang ke Bali khususnya tinggal di daerah Seminyak merupakan wisatawan yang menghabiskan libur lebih panjang.

Keputusan wisatawan untuk melakukan perjalanan wisata di Seminyak dipengaruhi oleh kondisi internal dan kondisi eksternal yang dimiliki wisatawan. Kondisi internal terkait dengan keinginan dan kemauan, rasa ingin tahu dan pengalaman yang muncul dari diri serta ditunjang dengan kemampuan biaya yang cukup, sedangkan kondisi eksternal terkait dengan keberadaan daya tarik, fasilitas, pelayanan di destinasi wisata serta kemudahan dari dan ke destinasi wisata Seminyak. Hal tersebut menjadi faktor yang memotivasi wisatawan untuk memutuskan datang ke Bali dan Seminyak.

Hal ini diperkuat menurut Burkat dan Medlik (Keliwer dan Nurcahyo, 2015) bahwa keputusan wisatawan untuk melakukan perjalanan wisata di dorong oleh 2 faktor yaitu faktor pendorong dan penarik. Faktor pendorong merupakan faktor yang dapat menyebabkan seseorang untuk memutuskan melakukan perjalanan wisata, faktor ini berupa ingin melepaskan kejenuhan dari pekerjaan sehari-hari, pengakuan diri untuk menaikan status sosial, melakukan interaksi sosial dengan masyarakat, alam dan budaya, serta sebagai bentuk aktualisasi diri.

Motif wisatawan dalam melakukan kegiatan wisata di Seminyak sangatlah beragam, diantaranya untuk tujuan santai bersama teman dan keluarga, menghilangkan kejenuhan sehari-hari, selain itu juga untuk kesehatan yaitu mendapatkan cahaya matahari yang tidak didapatkan di negara asal, suasana yang tenang dan keindahan pantai Seminyak serta sarana, prasarana dan fasilitas yang lengkap di Seminyak membuat wisatawan betah berlama-lama di Seminyak guna melepaskan stres akibat rutinitas sehari-hari ditempat asal.

Memperoleh kegembiraan dan bersenang-senang menikmati matahari terbit dan matahari tenggelam, berselancar, berkuda dan melakukan aktifitas pantai lainnya, sehingga dapat disimpulkan bahwa motivasi wisatawan yang berkunjung ke Bali dan Seminyak dengan berbagai macam alasan dan tujuannya.

Selain keindahan alam yang dimiliki Bali dan Seminyak, keramahtamahan dan pelayanan yang prima yang selalu diberikan oleh masyarakat lokal membuat wisatawan nyaman tinggal berlama-lama di Seminyak. Hal ini dikuatkan dengan hasil penelitian Sutarso, 2012 bahwa Pengembangan pariwisata tidak boleh meminggirkan budaya dan spirit lokal. Oleh karena itu perlu digagas pengembangan pariwisata yang sejalan dengan pengembangan budaya dan semangat masyarakat lokal beserta cipta, rasa dan karsanya.

\section{KESIMPULAN DAN SARAN}

\subsection{Kesimpulan}

1. Wisata Bali dan Seminyak merupakan kerja sama yang terkoordinir antara pemerintah daerah, dinas pariwisata, pelaku bisnis dan masyarakat setempat untuk menciptakan kegiatan pariwisata dan media promosi wisata sehingga bisa menarik perhatian wisatawan untuk berkunjung ke Seminyak.

2. Pelayanan prima dan pengetahuan dari masyarakat lokal untuk mendukung aktivitas kepariwisataan di Bali dan Seminyak merupakan salah satu indikator wisatawan nyaman untuk tinggal berlama-lama dan tidak sedikit yang datang kembali ke Bali setelah balik ke negaranya.

3. Pemasaran dan promosi melalui media konvensional dan media massa yang tepat akan membantu memberikan informasi yang akurat tentang keindahan wisata alam dan budaya yang dimiliki Bali dan Seminyak untuk menarik perhatian wisatawan lokal dan asing untuk datang berkunjung.

\subsection{Saran}

1. Keterlibatan dan kerjasama dalam merencanakan berbagai kegiatan kepariwisataan antara pemerintah daerah, dinas pariwisata, pelaku bisnis pariwisata dan masyarakat lokal dalam mengelola dan mengembangkan wisata alam dan wisata budaya di Seminyak Bali harus tetap dilakukan agar daya tarik wisatawan berkunjung ke Seminyak Bali terus meningkat.

2. Pengetahuan masyarakat lokal tentang kepariwisataan harus tetap dioptimalisasikan sehingga dalam melayani wisatawan dapat secara prima. 


\section{DAFTAR PUSTAKA}

Atiko Gita, Ratih Hasanah Sudrajat, Kharisma Nasionalita. (2016). Analisis Strategi Promosi Pariwisata Melalui Media Sosial Oleh Kementerian Pariwisata RI (Studi Deskriptif Akun Instagram @indtravel). Jurnal Sosioteknologi. Vol. 15, No 3, Desember 2016.

Antari, Ni luh Sili. (2013). Peran Industri Pariwisata Terhadap Penerimaan Pendapatan Asli Daerah Kabupaten Gianyar. Jurnal Perhotelan dan Pariwisata. Vol. 3, No 1 Agustus 2013: 35-45.

Budiani Sri Rahayu, Wahdaningrum Windarti, Yosky Dellamanda, Pratama Hendra S, Mulandari Henny, Iskandar Heu Nur Taufiq, Alphabettika Mica, Maharani Novela, Febriani Rizka Fitria, Kusmiati Yanti. (2018). Analisis Potensi Dan Strategi Pengembangan Pariwisata Berkelanjutan Berbasis Komunitas di Desa Sembungan Wonosobo, Jawa Tengah. Majalah Geografi Indonesia, Vol. 32, No 2 September 2018: 170176.

Cangara Hafied. 2013. Perencanaan dan Strategi Komunikasi. Jakarta: Raja Grafindo Persada.

Hendarto A.K. (2008). Ekowisata: Sebuah Diferensiasi Produk Pariwisata di Indonesia Pasca Tragedi Bali (Online). http://www.wisatamelayu.co/id/article.php?a=Zwngl3

Hidayat Surahman. (2017). Peranan Hotel Lombok Raya Terhadap Masyarakat Sekitar dan Daya Dukungannya Terhadap Kebutuhan Sektor Pariwisata di Pulau Lombok. Jurnal Valid, Vol. 14, No 2.

Hidayat Marcella. (2011). Strategi Perencanaan dan Pengembangan Objek Wisata (Studi Kasus Pantai Pangandaran Ciamis, Jawa Barat). Tourism and Hospitality Esensial Journal. Vol. 1, No 1, 2011: 33-44.

Kanom. (2015). Strategi Pengembangan Kuta Lombok Sebagai Destinasi Pariwisata Berkelanjutan, Jurnal Magister Pariwisata, Vol. 2, No.1: 25-42.

Keliwar, Said dan Nurcahyo, Anton. 2015. Motivasi Dan Persepsi Pengunjung Terhadap Objek Wisata Desa Budaya Pampang Di Samarinda. Jurnal Manajemen Resort dan Leisure, Vol. 12, No. 2, Oktober 2015: 10-27.

Moleong, Lexy. J. (2010). Metodologi Penelitian Kualitatif, Bandung: Remaja Rosdakarya.
Nevita Septria. (2017). Pemanfaatan Media Dalam Promosi Pariwisata Kabupaten Pesisir Selatan (Studi pada Disparekraf Pora Kabupaten Pesisir Selatan). Tesis: Program Magister Ilmu Komunikasi Fakultas Ilmu Sosial Ilmu Politik, Universitas Andalas.

Pratiwi Beta Desi dan Pinasti Indah Sri. 2017. Pariwisata dan Budaya (Studi Peran Serta Masyarakat Lokal dalam Pengelolaan Pariwisata di Kampung Pitu, Nglanggeran, Patuk, Gunung Kidul). Jurnal Pendidikan Sosiologi.

Rogers EM. (2003). Diffusion of Innovations. New York: A Division of Macmillan Publishing Co. Inc.

Situmeang Ilona Vicenovie Oisina., Sugianto, Angelia Sulistiwaty. (2017). The Identification Of Persuasive Message Campaign, "Wonderful Indonesia 2015”. Jurnal ASPIKOM. Vol. 3, No 3 Juli 2017.

Situmeang, Ilona Vicenovie Oisina. 2016. Corporate Social Responsibility Dipandang Dari Perspektif Komunikasi Organisasi. Yogyakarta: Ekuilibria.

Situmorang, Syafrizal Helmi. 2008. Destination Brand: Membangun Keunggulan Bersaing Daerah. Jurnal Perencanaan dan Pengembangan Wilayah. Jurnal Wahana Hijau, Vol. 4, No 2 , Desember 2008.

Soemantri. (2008). Keunggulan Bali sebagai Daerah Tujuan Wisata Andalan Indonesia. Jurnal Seminar Ikatan Geografi Indonesia.

Sugiyarto dan Amaruli Rabith Jihan. 2018. Pengembangan Pariwisata Berbasis Budaya Dan Kearifan Lokal. Jurnal Administrasi Bisnis. Vol. 7, No 1, Maret 2018: 45-52.

Sutarso Joko. (2012). Menggagas Pariwisata Berbasis Budaya dan Kearifan Lokal. Prosiding Seminar Nasional "Menggagas Pencitraan Berbasis Kearifan Lokal" dalam rangka Dies Natalis Jurusan Ilmu Komunikasi Univ. Jend. Soedirman Ke-14 hal: 505-515.

Suwarto, Titania. (2011). Pengaruh Iklim dan Perubahan Terhadap Destinasi Pariwisata Pangandaran. Jurnal Perencanaan Wilayah Kota, Vol. 22, No 1, April 2011:17-32.

Wijaya Kandi. (2015). Masa Depan Pariwisata Bali (Perspektif Permasalahan dan Solusinya). Journal of Research in Economic and Management, Vol. 15, No 1, Januari-Juni 2015: 118135. 